\title{
Chapter 5 Negotiating Equality: Minority Protection in the Versailles Settlement
}

León Castellanos-Jankiewicz"

\section{Introduction}

Although they are not considered the legacy precedents of human rights today, the interwar minorities treaties contributed to developing the legal standard of equality before the law, which would become the keystone of the international human rights regime after the Second World War. The minority protection standards were also the first international rights that were embedded in an international organization. This regime is therefore useful in providing us with an understanding of the origins of later human rights treaties, since the notion of equality they contained is not dissimilar to that outlined in the Universal Declaration and subsequent international instruments of a binding nature. ${ }^{1}$

This chapter reviews the travaux préparatoires of the interwar minorities treaties, which reflect a broad concern for equality and non-discrimination. Its central proposition is that the international protection of minorities was primarily designed to develop a liberal-democratic agenda premised on equality before the law in order to allay the concerns of national minorities in Eastern Europe. This cause was supported by United States President Woodrow Wilson, whose democratic outlook set the tone of the 1919 Paris peace conference.

The first section of the chapter begins by presenting the plight of minorities during the Great War and surveys the war aims of the Great Powers in relation to this problem. It emerges that minority protection was regarded as instrumental in achieving the Allied objectives of spreading democracy and fulfilling nationalist aspirations. The role of self-determination in reconciling the contradictions of these competing notions is also explained through a discussion of Woodrow Wilson's Fourteen Points and their connection to the protection of national minorities.

* Researcher, TMC Asser Institute for International and European Law, The Hague.

1 Max Sørensen, 'The Quest for Equality' (1956) 31 International Conciliation 291346. 
The chapter's second section focuses on the drafting process of the minority protection regime, which, it is argued, came close to becoming a universal human rights regime premised on the internationalization of equal treatment with regard to certain rights. This claim is supported through an examination of several high-profile proposals to incorporate racial and religious equality into the Covenant of the League of Nations as generally binding norms. Religious freedom clauses were put forward by Woodrow Wilson and supplemented by Britain's Lord Cecil, whereas a much more contentious racial equal equality clause was championed by Baron Makino from Japan. All these proposals floundered, but the setbacks prompted Wilson to press on with the minorities issue in Central Europe. The chapter concludes by presenting the drafting of the equality clauses in the influential Polish Treaty, which would be included in subsequent human rights instruments.

\section{National Minorities and the Great War}

This section discusses the liberal ideas that defined nationalist causes during World War I and their relationship to the debates about the equal treatment of minorities. It begins by presenting the most notable wartime incidents of minority abuse with an emphasis on government-sanctioned mistreatment of citizens, such as the massacres of Armenians in Turkey. This is followed by a discussion of the Allies' war aims, where the welfare of national minorities was treated as a distinct priority. An additional section presents the Wilsonian idea of democracy to understand the rationales behind the President's insistence on protecting minorities. Finally, Woodrow Wilson's major wartime speeches are presented, and it emerges that minorities featured prominently therein, especially in the Fourteen Points and the Four Principles. The discussion of these pronouncements concludes the section and is followed by the drafting process of the minorities provisions for the League of Nations Covenant.

\subsection{Wartime Mistreatment of Minorities}

Soon after the Versailles Peace Conference opened on 18 January 1919, the peacemakers created the Commission on the Responsibility of the Authors of the War and on Enforcement of Penalties. This body was charged with reporting on the violations of international law committed by the Central 
Powers (Germany and Austria-Hungary) and their allies (Turkey and Bulgaria). The Commission's mandate included the controversial question of responsibility for the outbreak of the war, the facts surrounding breaches of the laws and customs of war and the possible constitution of an international criminal tribunal that would adjudicate on offenses committed. ${ }^{2}$

In its summary, the report presented instances of mistreatment of minorities. It documented a massacre in Turkey of 200,000 Armenians 'systematically organized with German complicity' and committed by Turks. Also listed against Turkey was the abduction of Greek girls and women for the purpose of enforced prostitution, as well as the pillage of some 600 Greek villages. A section entitled 'Attempts to denationalise the inhabitants of occupied territory' mentioned the imposition of national characteristics on the population, the destruction of schools and churches, and beatings for saying 'good morning' in Serbian. ${ }^{3}$

The massacres of Armenian minorities in the Ottoman Empire received considerable attention and the Allies actively sought to bring those responsible to justice. Turkey's campaign against its Armenian citizens claimed between eight hundred thousand and 1.3 million lives in $1915 .{ }^{4} \mathrm{~A}$ joint diplomatic note issued by France, Great Britain and Russia denounced these purges as 'crimes against humanity and civilization' noting the connivance or assistance of Turkish authorities and vowing to bring those responsible to account. ${ }^{5}$

2 'Report of the Commission on Responsibility of the Authors of the War and Enforcement of Penalties' in Violation of the Laws and Customs of War, Reports of Majority and Dissenting Reports of American and Japanese Members of the Commission of Responsibilities, Conference of Paris, 1919 (Clarendon 1919) 1, 2. The Commission's Minority Report is reproduced in 4 AJIL (1920) at 95-154. The 1919 edition is cited here as 'Minority Report of the Commission on Responsibility'. Members of the Commission included James Brown Scott, Nicolas Politis, and Édouard Rolin-Jaequemyns. It was chaired by U.S. Secretary of State Robert Lansing, and Albert de Lapradelle acted as Secretary. Scott and Lapradelle would later have a prominent role in the drafting of the Déclaration des droits internationaux de l'homme issued on 1929 by the Institut de Droit International.

3 Report of the Commission on Responsibility... (n 2) 30, 34, 39, 40.

4 Toynbee circumscribes the Armenian massacres within the first 'war of extermination' carried out in the name of the principle of nationalities during the GrecoTurkish War of 1919-1922A. Arnold Toynbee, The Western Question in Greece and Turkey (Constable 1922) 259-319.

5 'Diplomatic note dated 28 May 1915', quoted in the Armenian Memorandum presented by the Greek delegation to the Commission of Fifteen of the Paris Peace Conference on 14 March 1919, cited in Arthur Beylerian, Les Grandes Puissances, 
The American Ambassador to the Ottoman Empire also reported persecutions of 'unprecedented proportions' and warned the United States Secretary of State that a 'campaign of race extermination' was underway. ${ }^{6}$ Five years later, in the Treaty of Sèvres, the Allies duly amputated the Armenian territories from the Ottoman Empire and sought to punish those responsible for the atrocities. ${ }^{7}$ But the attempts at redressing the plight of minorities in Turkey were short-lived. The collapse of the Sultanate took the demobilized Allies by surprise and was quickly followed by Mustafa Kemal's seizure of power. When Kemal refused to ratify Sèvres, the resulting Lausanne Treaty made no mention of accountability for the genocide of Armenian minorities. Instead, it granted a blanket amnesty to all the inhabitants of Turkey and Greece for offenses that occurred during that conflict and the Greco-Turkish war of $1919-1922 .{ }^{8}$

This episode underscored the need to develop general international rules to protect minority populations from their abusive governments during armed conflict. Given the minorities' sacrifices, the Paris Peace Conference was sympathetic to their rehabilitation, not least because of the pressing need to establish stable borders in Central and Eastern Europe. In his opening speech to the Conference, for instance, Raymond Poincaré, the French President, honored the 'captive nationalities' that had rallied to the Allied colours:

The Yugo-Slavs, the Armenians, the Syrians and Lebanese, the Arabs, all the oppressed peoples, all the victims long helpless or resigned, of great historic deeds of injustice, all the martyrs of the past, all the out-

l'Empire ottoman et les Arméniens dans les archives françaises (1914-1918) (Publications de la Sorbonne 1983) 29.

6 Morgenthau to Secretary of State, telegram of 16 July 1915: 'Deportation of and excesses against peaceful Armenians is increasing and from harrowing reports of eye witnesses it appears that a harrowing campaign of race extermination is in progress under pretext of a reprisal against rebellion. Reprinted in: Alan Whitehorn, The Armenian Genocide: The Essential Reference Guide (ABC-CLIO 2015) 295.

7 Art 88 provided that 'Turkey...hereby recognises Armenia as a free and independent State.' Treaty of Peace between the Allied and Associated Powers and Turkey (signed 10 August 1920) 28 LNTS 225 (Treaty of Sèvres).

8 That is, for acts committed between 1 August 1914 and 20 November 1922. 'Declaration of Amnesty' in 18 AJIL Supplement: Official Documents (1924) 92-95, art 3 at 93. Moreover, all judicial decisions pronounced in this regard were to be annulled, and any ongoing proceedings were to be stayed: art 5 at 93 . The Treaty of Lausanne was signed on 24 July 1923 and is reprinted in 18 AJIL Supplement: Official Documents (1924) 4-53. 
raged consciences, all the strangled liberties, revived at the clash of our arms and turned towards us as their natural defenders. ${ }^{9}$

Poincaré's sympathies reflected the espousal of the principle of national self-determination that had been incorporated to the Allies' war aims by the end of the conflict. These aims are briefly presented in the next section and are followed by a detailed treatment of Woodrow Wilson's novel ideas on 'democratic diplomacy' and self-determination, which foreshadowed the inclusion of the equality clauses.

\subsection{The Allies' War Aims and National Minorities}

We need to understand the attitudes of the Allied Powers towards nationalism as captured in their war aims in order to grasp the ethos of interwar minority protection, since these objectives greatly defined the development of equality and non-discrimination during the interwar period. ${ }^{10}$ In Eastern Europe, the Allies focused on stabilizing the region through the creation of new liberal states in the wake of the dissolution of the Austro-Hungarian, German and Ottoman Empires.

More than any other Allied leader, Woodrow Wilson sought to outline preconditions for peace prior to the Paris peace conference. His note to the belligerents contains the first reference to a permanent international organization that would replace the old structure, as each power should be 'ready to consider the formation of a league of nations to ensure peace and justice throughout the world. ${ }^{11}$ The Allied governments engaged actively with Wilson's outlook, as demonstrated in their response to a German note linking sovereign equality with the principle of nationalities that underpinned minority protection:

9 'Plenary Session of 18 January 1919' in David Hunter Miller, My Diary of the Conference at Paris, with documents (20 vols, Appeal Printing Company 1925), vol 3, 399 (hereinafter Diary).

10 The Principal Allied Powers were the British Empire, France, Italy and Japan. When the United States declared war on Germany in April 1917, it entered the war as an 'Associated Power'. Thenceforth, the coalition was referred to as the Allied and Associated Powers.

11 'Note of President Wilson of 18 December 1918' in James Brown Scott (ed), Official Statements of War Aims and Peace Proposals December 1916 to November 1918 (Carnegie Endowment 1921) 12-15. 
no peace is possible as long as ... the acknowledgement of the principle of nationalities and of the free existence of small States shall not be assured; as long as there is no assurance of a settlement to suppress definitely the causes which for so long a time have menaced nations and to give the only efficacious guarantees for the security of the world. ${ }^{12}$

The Allies further outlined the implications of these ideas for minorities in a reply to Wilson's note. There, they called for the reorganization of Europe based on 'respect for nationalities and on the right to full security and liberty of economic development possessed by all peoples, small and great. ${ }^{13}$ They also sought the liberation of Rumanians and Czecho-Slovaks from foreign domination and the enfranchisement of European peoples in Turkey. ${ }^{14}$ By the end of 1917, British Prime Minister Lloyd George was calling for the liberation of the peoples subject to the Ottoman Empire (notably the bereaved Armenians), and for the self-determination of the German Empire's holdings. The future of these colonies, he declared, should be settled upon the principle of respecting the desires of the peoples themselves. ${ }^{15}$

In addition to self-determination, the Entente's objectives aimed at securing stability in Central and Eastern Europe on the basis of national affinities. In a draft memorandum of 1916, the Foreign Office recognized that the fulfillment of nationalist aspirations through statehood would ensure peace. ${ }^{16}$ However, the satisfaction of nationalist claims was impracticable when confronted with promises made in the form of territorial concessions to other allies. ${ }^{17}$ Beyond these commitments, it was clear that certain minorities would remain enclosed in states whose predominant nationality

12 'Entente Reply to German Proposals of 29 December 1916' in Brown Scott (n 11) 28.

13 'Entente Reply to President Wilson of 10 January 1917' in Brown Scott (n 11) 3538.

14 ibid 37. See also: Robert de Caix, 'War Aims of the Allies' (1917) 205 The North American Review 530, 532.

15 'Full text of Lloyd George's Speech on War Aims in House of Commons' The New York Times (New York, 24 December 1917) 3.

16 A tentative memorandum of the Foreign Office reveals this much. See the memorandum reproduced in David Lloyd George, The Truth about the Peace Treaties (Gollancz 1938) vol 1, 31, 32: 'no peace can be satisfactory to this country unless it promises to be durable, and an essential condition of such a peace is that it should give full scope to national aspirations as far as practicable.'

17 The Sykes-Picot secret agreement was one such instance where Great Britain and France established their spheres of influence in Southwestern Asia in anticipation of the collapse of the Ottoman Empire. See 'The Sykes-Picot Agreement: 1916' in 
was unlike their own, further complicating matters. The minority protection regime was the answer to these problems, for it recognized the personal attachment of irredentist persons to their heritage and nation without impinging on the territorial integrity of states while ensuring a modicum of equal treatment.

Problematically, Wilson assumed that American democratic values could be imported to the European context. But, instead of kindling the liberal spirit of deliberative democracy, he provoked the ethnic and conservative nationalisms that had lain dormant in Eastern Europe since the abortive revolutions of $1848 .{ }^{18}$ His pledge to fight for 'the rights of nations great and small and the privilege of men everywhere to choose their way of life and of obedience' resonated with European national minorities, but also across the colonial world where imperial footholds had shown their first signs of wear. ${ }^{19}$ Of course, the European Allies would later refuse to release their colonial possessions, and confined themselves to dismantling the empires of the defeated Central Powers. Instead of annexing these territories, they took it upon themselves to administrate them through the League's mandate system, and to establish the minority protection regime. ${ }^{20}$ Despite these setbacks, the projection of Wilson's principles of self-government onto America's war aims marked a turning point. His insistence that they should also define the parameters of the peace negotiations would be reflected in the Conference's final outcome. For the first time, a major international peace conference took a principled stance on democratic governance, as evidenced in the creation of new states along national lines, the use of plebiscites, and the provisions on minority protection.

Reeva S Simon and Eleanor H Tejirian (eds), The Creation of Iraq, 1914-1921 (Columbia University Press 2004) 165-68.

18 Mohammad Shahabuddin, "The Ethnic Dichotomy of "Self" and "Other" within Europe: Inter-War Minority Protection in Perspective' in Duncan French (ed) Statehood and Self-Determination: Reconciling Tradition and Modernity in International Law (CUP 2013) 407-426.

19 Erez Manela, The Wilsonian Moment: Self-Determination and the International Origins of Anticolonial Nationalism (OUP 2007).

20 Susan Pedersen, The Guardians: The League of Nations and the Crisis of Empire (OUP 2015). 


\subsection{Woodrow Wilson's Fourteen Points and Self-Determination}

When Wilson cast his war aims around the Fourteen Points, his ideas gave expression to the aspirations held by Europe's national minorities for political autonomy and equality of treatment. The foremost of these principles was national self-determination, which originates from the political statements made by Wilson during the Great War, and which was synonymous with democratic self-government, although it stopped short of advancing external independence. The term's meaning has varied since, and self-determination went on to become the banner of independence from colonial rule after 1945 .

Wilson emphasized that self-rule and democratic representation were the keystones of peace. Although he did not coin the term himself, 'selfdetermination'-understood as the political independence of nations through the exercise of democracy-emerged as a corollary of his ideas on self-government:

No peace can last, or ought to last, which does not recognize and accept the principle that governments derive all their just powers from the consent of the governed. ${ }^{21}$

Wilson's program was a democratic one and his ideas found resonance among Europeans at large, but especially among national minorities still under the imperial yoke. Self-determination thus became the vessel for nationalist aspirations. The tensions resulting from this unusual mixture of American democratic ideals and European nationalism significantly dominated the lifespan of the League of Nations and was embodied in various forms, including the creation of national states, the establishment of the mandates system, the reliance on democratic plebiscites to determine territorial frontiers, the multilateral system of minority protection, reciprocal emigration arrangements and population exchanges. ${ }^{22}$

The most iconic of Wilson's wartime statements was the Fourteen Points speech of 8 January 1918, where he outlined America's war aims while denouncing the European practices of annexation, conquest and secret

21 'President Wilson's Address of January 22, 1917' 11 ASIL Supplement: Official Documents (1917) 318-323 (hereinafter referred to as Wilson's 'Peace without Victory' speech).

22 Nathaniel Berman, "But the alternative is despair": European nationalism and the modernist renewal of international law' (1993) 106 Harvard Law Review 17921903. 
covenants. ${ }^{23}$ The importance of the Fourteen Points is compounded by the fact that Germany surrendered to the Allies on the understanding that the peace treaties would be concluded around these principles. In his speech, Wilson also made his first public reference to what later became the League of Nations by speaking of 'a general association' that could guarantee the territorial and political integrity of all states after the war. ${ }^{24}$

Although they did not contain an explicit reference to self-determination, the Fourteen Points espoused the nationalities principle in full. Frontiers were to be readjusted along national lines in Italy, Austria-Hungary and the Balkans. The Italian state was to have 'clearly recognizable lines of nationality' and the subject peoples of Austria-Hungary were to be accorded 'the freest opportunity to autonomous development'. In the former Ottoman Empire, the (Christian) nationalities under Turkish rule 'should be assured an undoubted security of life and an absolutely unmolested opportunity for autonomous development.' The Polish state was to resurface and would comprise vast territories inhabited by indisputably Polish populations. Finally, relations among the Balkan states should be determined 'along historically established lines of allegiance and nationality'

In his 'Peace without Victory' address to the Senate, Wilson expounded his ideas on representative government and the equality of states. No nation, he prayed, 'should seek to extend its polity over any other nation or people.' Every people should be free to determine its own polity 'unhindered, unthreatened, unafraid. ${ }^{25}$ Wilson considered the equality of nationalities to be inextricably linked to the equality of nation-states. To him, these were two sides of the same coin. He took the equality of states to mean a formal 'equality of rights' that did not differentiate between powerful and weak states. Since geography and historical happenstance ruled out equality of territory and resources, equal rights among nations could only be achieved 'in the ordinary peaceful and legitimate development of the peoples themselves. ${ }^{26}$

Wilson's worldview centered on the free development of peoples and groups. He used the words 'nations' and 'peoples' in a loose, equivocal way. The terms oscillate between the idea of states and that of ethnic na-

23 Woodrow Wilson, 'The Fourteen Points Address of 8 January 1918' in Arthur B. Keith (ed), Speeches and Documents on International Affairs (1918-1937) (OUP 1938) $1-8$.

24 Joachim Schwietzke, 'Fourteen Points of Wilson (1918)' in Rüdiger Wolfrum (ed), Max Planck Encyclopedia of Public International Law (OUP 2007).

25 Wilson, 'Peace Without Victory' (n 21) 323.

26 ibid 321. 
tionalities. Yet, he never suggests that individuals should be entitled to international rights and always used the language of collectives to advance his democratic agenda. ${ }^{27}$

It follows that, for Wilson, good governance is a precondition to individual freedom. The recognition of disenfranchised collectives through the elimination of state-based discrimination was his goal. In other words, he was agitating for the 'right to have rights' of persons regarded as secondclass citizens or stateless persons because of their identification with a national or ethnic minority. ${ }^{28} \mathrm{He}$ sought to achieve this by ensuring their equal rights in the peace settlement. Almost overnight, the expansive individual entitlements of the minorities treaties that had been, until then, reserved only to some, became accessible to a broader range of subjects in those states. In the same stroke, as it were, the equality of all nationals 'before the law' became an international standard of treatment for the first time ever in the minorities treaties. ${ }^{29}$

The nineteenth-century treaties protecting certain minorities had never offered so broad an interpretation of equality and instead confined themselves to piecemeal equality, that is, they granted equality in selected aspects of public and private life: equal access to, concurrently or alternatively, public offices, dignities, the courts, civic rights and political rights. ${ }^{30}$ Similarly, the pre-1919 practice alludes to the equal right to, concurrently or alternatively, peaceable existence, religious equality, or equality of economic opportunity. Equality 'before the law', as it appeared in the minorities treaties, was altogether different. It would later be enshrined in Article

27 ' $[\mathrm{H}]$ enceforth inviolable security of life, of worship, and of industrial and social development should be guaranteed to all peoples who have lived hitherto under the power of governments devoted to a faith and purpose hostile to their own.' ibid, emphasis added.

28 The 'right to have rights' was articulated by Hanna Arendt in The Origins of Totalitarianism (Meridian Books 1958). For a recent survey of the concept, see: Stephanie DeGooyer, Alastair Hunt, Lida Maxwell and Samuel Moyn, The Right to Have Rights (Verso 2018).

29 See art 7 Polish Minority Treaty: 'All Polish nationals shall be equal before the law and shall enjoy the same civil and political rights without distinction as to race, sex, language or religion. Emphasis added. Note that the presence of the word 'and' makes the 'equality before the law' guarantee a self-standing one. Treaty Between the Principal Allied and Associated Powers and Poland (signed 28 June 1919, entered into force 10 January 1920) 112 BSP 232.

30 For the most recent surveys, see Patrick Thornberry, International Law and the Rights of Minorities (Clarendon Press 1991) ch 2; Alfred W Brian Simpson, Human Rights and the End of Empire: Britain and the Genesis of the European Convention (OUP 2004) ch 3. 
7 of the Universal Declaration ${ }^{31}$ and in Article 26 of the International Covenant on Civil and Political Rights. ${ }^{32}$ The minorities regime elevated the principle of equality before the law to the international legal plane as a rule, but also as an interpretative tool for the formulation of other individual rights. Herein lies the unique contribution of the minorities treaties, which, in seeking to construct inclusive societies through group-levelling, broadened the scope of internationally-protected rights to include any class of invidious treatment or discrimination on the part of governments. To Wilson, this was not simply a matter of domestic stability, but also one of international peace. 'Nothing, he ventured, 'is more likely to disturb the peace of the world than the treatment which might in certain circumstances be meted out to minorities. 33

Barely a month after outlining his Points, Wilson declared that 'every territorial settlement involved in this war must be made in the interest and for the benefit of the populations concerned, and not as a part of any mere adjustment or compromise of claims amongst rival states.34 In that address, known as the Four Principles, he explicitly refers to ethnic minorities as sub-state entities. ${ }^{35}$ The foremost concern for minorities is much more explicit in this speech: 'peoples and provinces are not to be bartered about

31 Universal Declaration of Human Rights (adopted 10 December 1948 UNGA Res $217 \mathrm{~A}(\mathrm{III})$ (UDHR) art 7: 'All are equal before the law and are entitled without any discrimination to equal protection of the law. All are entitled to equal protection against any discrimination in violation of this Declaration and against any incitement to such discrimination. Emphasis added. As in the Polish Treaty, the 'equality before the law' construction is also a self-standing guarantee.

32 International Covenant on Civil and Political Rights (adopted 19 December 1966, entered into force 23 March 1976) 999 UNTS 171 (ICCPR) art 26: 'All persons are equal before the law and are entitled without any discrimination to the equal protection of the law. In this respect, the law shall prohibit any discrimination and guarantee to all persons equal and effective protection against discrimination on any ground such as race, colour, sex, language, religion, political or other opinion, national or social origin, property, birth or other status.' Emphasis added.

33 'Speech by President Wilson of May 1st, 1919, Plenary Session of the Peace Conference' in Louis B Sohn and Thomas Buergenthal (eds), International Protection of Human Rights (Bobbs-Merrill 1973) 217.

34 Wilson to Congress (11 February 1918) 46 The Papers of Woodrow Wilson 318324. The address is known as the Four Principles and was intended to supplement Wilson's Fourteen Points. Hereinafter referred to as Wilson's 'Four Principles' speech.

35 ibid. The plight of 'small nations and of nationalities' stemmed from their lack of unity, which in turn impeded their ability to 'determine their own allegiances and their own forms of political life.' Ultimately, the war 'had its roots in the disregard of those rights' and new Covenants would avoid this. 
from sovereignty to sovereignty as if they were mere chattels and pawns in a game, even the great game, now forever discredited, of the balance of power. ${ }^{36}$ The challenge for Wilson to reconcile the state sovereignty and imperial rivalries with minimal guarantees for minorities was considerable by any measure. ${ }^{37}$ His vision involved an understanding among nations through the language of democracy, not statehood; he believed the state was merely instrumental, its existence and purpose subordinate to its constituent parts. These images of a pan-democratic world alliance informed Woodrow Wilson's advocacy for the new concept of self-determination.

America's position as the single most important power in 1919, combined with Wilson's messianic persona, stoked these sentiments and raised expectations that - for the most part - would never be fulfilled. But, at Paris, Wilson insisted on designing the peace treaties on the basis of national lines and ethnographic affinities as outlined in the Fourteen Points. Speaking at the plenary of the Paris Peace Conference, he stressed that a peaceful settlement would entail making 'an equitable distribution of territories according to the race, the ethnographical character of the people inhabiting those territories. ${ }^{38} \mathrm{He}$ even hectored his British, French and Italian counterparts to accept these terms:

Except where nearly impassable frontiers forced themselves upon us, such as the one drawn by the crests of the Alps, we have followed the boundaries traced by ethnographic affinities, according to the right of self-determination. ${ }^{39}$

The states subject to minorities obligations were latecomers to the nationbuilding process who had yet to fully develop representative political institutions; yet, their European heritage disallowed their subordination to mandates, and colonial claims were out of the question lest the European civilizing mission be tarnished and ridiculed. For postwar planners, the challenge was to channel their primitive nationalism into the orbit of west-

36 ibid.

37 Carole Fink, 'The Minorities Question at the Paris Peace Conference: The Polish Minority Treaty, June 28, 1919' in Manfred F Boemeke, Gerald D Feldman and Elisabeth Glaser (eds), The Treaty of Versailles: A Reassessment After 75 Years (German Historical Institute/CUP 1998) 249, 250.

38 Lloyd George (n 16) vol 2, 1377.

39 Paul Mantoux, The Deliberations of the Council of Four: (March 24-June 28, 1919): Notes of the Official Interpreter, (Arthur S Link tr, Princeton University Press 1992) vol 2, 226. 
ern liberal values. The eastern and western conceptions of group identity being different, the minority protection system would fill that gap. ${ }^{40}$

\section{Equality and the Covenant: Failure or Qualified Success?}

This section presents the drafting history of the minority protection regime at the Paris Peace Conference of 1919. It shows the inherent contradictions that plagued the system from the outset, such as the hypocrisy of the Great Powers in refusing to accept the principle of equal treatment as a universal standard. The principle's introduction to the League of Nations Covenant by Japan was explicitly rejected, with Woodrow Wilson presiding over its dispatch while maintaining (rather unconvincingly) that the idea of equality permeated the entire League structure. Minority protection was also excluded from the Covenant, lest the subjects of Britain's dominions obtain full status equality as regards their imperial overlords.

The few minorities provisions that were ultimately adopted were fraught with ambiguities; two unresolved questions would carry into the regime over the years to come. The states containing minorities pushed to assimilate the hitherto diverse populations inhabiting their newly minted borders. The Great Powers were sympathetic to their arguments: the goal, as Lloyd George put it, was to turn minorities into 'satisfied and faithful citizens. And yet, the Allies maintained that past instances of minority abuse would recur: 'I greatly fear', said Balfour ominously, 'that the Jewish problem will become one of the most serious in the future. ${ }^{41}$ Torn between setting up strong client states, on the one hand, and the assertion of their humanitarian sentiments, on the other, the Allies took a Solomonic stance by granting international rights to minorities while making it extremely difficult for them to assert these claims. Ultimately, the assimilation-versus-autonomy debate forced minorities and majorities into uncompromising positions, which, compounded by the Great Powers' aloofness, condemned the minorities regime to a stillborn existence. The second matter of contention was the international character of minority protection. It was a pioneering idea-the first multilateral guarantee of individual rights under modern international law-but its procedural intricacies prevented

40 To Berman, the debate opposed 'two different cultural conceptions of group identity - those of Western and Eastern Europe.' Nathaniel Berman, 'The International Law of Nationalism: Group Identity and Legal History' in David Wipmann (ed), International Law and Ethnic Conflict (Cornell University Press 1998) 25, 40-42.

41 Council of Four, Meeting of 23 June 1919, in Mantoux (n 39), vol 2, 527. 
the minorities from having direct access to its machinery. This changed in 1920, when an informal petition system was established. Over the years, this mechanism was formalized and streamlined, but its efforts came to naught when Hitler began disrupting European politics in the early 1930s.

Despite these setbacks, the main problem facing the incorporation of minorities into the general population was resolved by granting them citizenship, equal rights, and special measures of protection. Although not reflected in the Covenant, they subsisted in the exceptional regime of minority protection, thereby giving 'the right to have rights' to formerly disenfranchised peoples.

The League of Nations Covenant contains no clauses on minority protection and does not recognize equality and non-discrimination as standards of individual treatment, attesting to the exceptional nature of minority obligations and their limited application to a handful of states. The first American and British drafts of the League of Nations Covenant ignored the minorities question altogether. ${ }^{42}$ Although Woodrow Wilson was enthusiastic about the inclusion of minority provisions, his British counterparts preferred to solve the matter with border readjustments. This is perhaps why, instead of a minority protection clause, Woodrow Wilson's first draft of the League Covenant provides that all territorial readjustments following the war should be made in accordance with principle of self-determination (art 3). ${ }^{43}$ Attempts made to incorporate general clauses on racial equality and freedom of religion into the Covenant failed. An overview of

42 The earliest draft Covenant was circulated informally by the Phillemore Committee: 'The Phillemore Plan' dated 20 March 1918, in David Hunter Miller, The Drafing of the Covenant (GP Putnam's Sons 1928), vol 2, 3 (hereinafter Covenant). Upon receiving this document, Woodrow Wilson commissioned his advisors to venture a draft, and the task fell on Colonel House: 'Draft of Colonel House' dated 16 July 1918, ibid, vol 2, 7. Wilson wrote his first draft on the basis of House's text: 'Wilson's First Draft' ibid, vol 2, 12. Two other documents exercised considerable influence during the drafting process: the memorandum by General Jan Smuts, and Lord Robert Cecil's 'draft sketch' of the League. See Jan Smuts, 'The League of Nations: A Practical Suggestion' dated 16 December 1918 in Miller, Diary (n 9) vol 3, 31-64; and 'The Cecil Plan' dated 14 January 1919, in Miller, Covenant, vol 2, 61. Of the latter two, only Smuts refers to minorities.

43 The relevant passage reads: 'it is understood that between [the Powers] that such territorial readjustments, if any, as may in the future become necessary by reason of changes in present racial conditions and aspirations or present social and political relationships, pursuant to the principle of self-determination, and also such territorial readjustments as may in the judgment of three fourths of the Delegates be demanded by the welfare and manifest interest of the peoples concerned, may be effected, if agreeable to those peoples'. 'Wilson's First Draft of August 1918', in 
their fate is instructive in highlighting the main issues that were at stake before examining the minorities provisions in detail.

\subsection{Wilson's Equal Treatment Clauses}

Despite their leaders' reluctance, American and other officials had reached the preliminary conclusion that some form of international protection would be necessary in certain localities. A memorandum on American foreign policy and international law admitted this much in respect to the Balkans. ${ }^{44}$ Tellingly, the influential paper authored by General Smuts also singled out the plight of oppressed minorities in considerable detail, noting that the welter of multinational empires had constrained the freedom of their constituent nations. Any peace agreement made on the basis of inequality, bondage, and oppression of the smaller nationalities would fail, and a new approach was necessary. ${ }^{45}$ Smuts' program of nationalist emancipation reads as a blueprint for the systems of minority protection and mandated territories that were to come:

The vital principles are: the principle of nationality involving the ideas of political freedom and equality; the principle of autonomy, which is the principle of nationality extended to peoples not yet capable of complete independent statehood; the principle of political decentralization, which will prevent the powerful nationality from swallowing

Miller, Covenant (n 42) vol 2, 12-13. That article also contained a clause that was striking for its narrow construal of reserved domain: ‘.. The Contracting Powers accept without reservation that the peace of the world is superior in importance to every question of political jurisdiction or boundary?

44 'The American Program and International Law: Draft Memorandum by David Hunter Miller, dated 31 July 1918 in Miller, Diary (n 9) vol 2, 323-475, 422-23: 'Experience has shown that treaty provisions on the protection of racial and religious minorities are in no sense self-executing. In the case of such states as the Balkans, beyond the mere agreement of religious freedom and personal liberty must be effective provisions for publicity and remedy when essential rights are threatened or violated.'

45 Smuts (n 42) 36. Smuts blended his idealism with considerable doses of realism: 'The nationalities of Europe are in many cases animated by historic hostility to one another; the tendency will be for them to fly at one another's throats on very slight provocation ... In this and many other respects, the league will have a very real rôle to play as the successor to the empires. ibid 48 . 
the weak autonomy as has often happened in the now defunct European empires. ${ }^{46}$

The crowning jewel of these ideals was the League of Nations, coupled with an international guarantee to stabilize this decentralized system. In time, the small nations would become self-sufficient: 'Government by consent of the governed is our formula. ${ }^{47}$ It is no coincidence that Smuts' recipe for international stability chimed with Woodrow Wilson's ideas on self-determination..$^{48}$

At Paris, the first discussions on minorities took place in the League of Nations Commission, which was charged with drafting the new organization's Covenant. ${ }^{49}$ During its first meeting, Wilson, who insisted on chairing the proceedings, introduced a non-discrimination provision relating to religious freedom:

Art. 19. The High Contracting Parties agree that they will make no law prohibiting or interfering with the free exercise of religion, and that they will in no way discriminate, either in law or in fact, against those who practice any particular creed, religion, or belief whose practices are not inconsistent with public order or public morals. ${ }^{50}$

This clause already contains the notion of equality 'in law or in fact', which became ubiquitous in the minorities treaties. Deeming it too general in nature, Lord Robert Cecil proposed an amendment to Wilson's article. The result was an extremely progressive text aimed at staving off state-based religious intolerance and authorising the League Council to make direct representations towards ill-behaved governments on behalf of religious minorities:

Art. 19. Recognising religious persecution and intolerance as fertile sources of war, the High Contracting Parties agree that political unrest arising therefrom is a matter of concern to the League and authorise

46 ibid 50.

47 ibid 53.

48 Smuts is credited for drafting the UN Charter's Preamble. For an account linking the Preamble episode with his views on the Commonwealth, see: Peter Marshall, 'Smuts and the Preamble to the UN Charter' (2001) 358 The Round Table, 55-65.

49 The (sometimes inconsistent) English and French minutes of these meetings are in Miller, Covenant ( $\mathrm{n} 42$ ) vol 2, 229-33; 395-500. The meetings were held at the Hôtel Crillon, where the American delegation had been put up.

50 'First Meeting [of the League of Nations Commission] of 3 February 1919', ibid, vol 2, 237. 
the Executive Council, wherever it is of opinion that the peace of the world is threatened by the illiberal action of the Government of any State towards the adherents of any particular creed, religion or belief, to make such representations or take such other steps to put an end to the evil in question. ${ }^{51}$

If Wilson's proposal had been daring, Cecil's amendment was completely unacceptable. The clause was rejected outright, a clear sign that equality in religious matters were not considered as generally binding under international law. Indeed, David Hunter Miller, Wilson's chief legal advisor in Paris, informed the President that the text went 'very far, and, I think, farther than any other provision in the Covenant. ${ }^{52}$ Nor was the article well received by Wilson's colleagues in the Commission, who were clearly apprehensive about extending the pale of recognition to their own subnational groups. ${ }^{53}$ In response, Wilson watered down the clause by incorporating a public order exception:

The High Contracting Parties agree that they will make no law prohibiting or interfering with the free exercise of religion, and they resolve that they will not permit the practice of any particular creed, religion, or belief, whose practices are not inconsistent with public order or with public morals, to interfere with the life, liberty or pursuit of happiness of their people. ${ }^{54}$

This article was adopted in the Committee's Seventh Meeting, with Léon Bourgeois approvingly noting its resemblance to the religious freedom

51 'Sixth Meeting [of the League of Nations Commission] of 8 February 1919', ibid, vol 2, 276.

52 ibid vol 1, 196.

53 Hymans (Belgium) flatly rejected the proposition of enabling the League to pronounce itself on domestic matters; Batalha Reis (Portugal) deemed the clause unacceptable for governments that recognized an official religion; Italy's Orlando warned of potential conflicts with constitutional dispositions; and Bourgeois believed such instances were already covered in the Covenant's draft article 9 (final art 11(2)) which dealt with internal disturbances and the 'friendly right' of all League members to bring such matters to the Organization's attention. ibid vol 2, 273-27, 441.

54 'Seventh Meeting [of the League of Nations Commission] of 10 February 1919' ibid vol 2, 282, 286-87. The French text is better drafted: 'Les Hautes Parties Contractantes décident qu'elles ne permettront pas que leurs citoyens, adhérents d'une foi, religion ou croyance quelconque, qui ne porte pas atteinte a l'ordre ou aux moeurs publiques, soient pour cette raison inquiétés dans leur vie, leur liberté et leur poursuite du bonheur.' ibid vol 1, 196. 
clause in the French Declaration of 1789.55 But 'in view of the complications', the article was removed from the draft Covenant in the Ninth Meeting. ${ }^{56}$

Wilson's provision on equality of treatment for ethnic minorities followed the same fate. This clause provides a clear indication that one of Wilson's main goals in establishing the minority protection regime was the elimination of the legal disabilities that were attached to group membership. Following the Treaty of Berlin of 1878 , the clause conditions recognition to the equal treatment of minorities and presupposes that protected individuals could also be aliens:

VI. The League of Nations shall require all new States to bind themselves as a condition precedent to their recognition as independent or autonomous States, to accord to all racial or national minorities within their several jurisdictions exactly the same treatment and security, both in law and in fact, that is accorded the racial or national majority of their people. ${ }^{57}$

When reviewing its wording, Miller told the President that this article would be unacceptable to his peers. ${ }^{58}$ Wilson promptly amended the provision in his Second Paris Draft by restricting the equal treatment standard between minorities and majorities only to those states seeking admission to the League. ${ }^{59}$ This would have entailed ubiquitous minority protection obligations for all new member states, but it would not bind the Great Powers. When this formulation too was rejected, it became apparent that

55 ibid vol 1, 282.

56 For the decision to omit the article, see: 'Ninth Meeting [of the League of Nations Commission]' of 13 February 1919, ibid, vol 2, 307. The minutes indicate that if there was 'a strong feeling in the Commission that some such provision should be inserted' the following drafting was suggested: 'The High Contracting Parties agree that they will not prohibit or interfere with the free exercise of any creed, religion, or belief whose practices are not inconsistent with public order or public morals, and that no person within their respective jurisdictions shall be molested in life, liberty, or in the pursuit of happiness by reason of his adherence to any such creed, religion, or belief. ibid vol 2, 307.

57 'Wilson's Second Draft or the First Paris Draft' dated 10 January 1919. ibid vol 2, 91. In his commentary, Miller observes that the article foreshadowed the subsequent minorities treaties. ibid 40.

58 ibid vol 1, 91. Miller's remarks are taken from his clause-by-clause commentary and suggestions to Wilson's First Paris Draft.

59 'Wilson's Third Draft or Second Paris Draft' dated 20 January 1919. ibid vol 2, 105. 
self-determination would only be materially relevant for a limited number of states.

Wilson's draft articles on religious and political equality are relevant because they became the backbone of the minorities provisions in the Polish Treaty. ${ }^{60}$ Their rejection from the Covenant stems from the reluctance to give the League too much supervisory power, from uncertainties surrounding the international standards of treatment required by the equality clauses and from the reluctance to extend favorable conditions to all persons in social, economic, and political matters. ${ }^{61}$

\subsection{Japan's Racial Equality Clause}

The Great Powers' apprehensiveness in extending equal treatment beyond European borders is illustrated through the well-known episode concerning the rejection of Japan's racial discrimination clause from the Covenant. ${ }^{62}$ By 1919, Japan had become rapidly modernized, commanded a first-class fleet, and enjoyed international prestige as a 'middle power' for its recent military victories. However, the Japanese were frequently sidelined in Paris for strategic reasons. The expansion of their interests towards the Pacific interfered with the United States' two-ocean navy policy and

60 Wilson's clauses were forwarded to the Committee on New States for incorporation to the Polish Treaty: 'I should mention that President Wilson's draft in regard to the protection of religious minorities was generally agreed to be satisfactory. It was hoped that it might be possible to draw up provisions in regard to Poland. 'Hankey to Dutasta', Miller, Diary (n 9) vol 13, 13-14. Maurice Hankey annexed Wilson's 'religious' and 'political' clauses to his note addressed to the conference's Secretary-General.

61 Italy proposed a clause for the Covenant guaranteeing equal access to working conditions regardless of citizenship: 'All laws and regulations intended to protect the rights and interests of workpeople shall be applied in every country without distinction of nationality'. States could still limit foreign workers from accessing certain kinds of work. The proposal was not adopted. See: 'Draft Scheme for the Constitution of the Society of Nations presented by the Italian Delegation' reproduced in Miller, Covenant (n 42) vol 2, 246-247.

62 Paul G Lauren, 'Human Rights in History: Diplomacy and Racial Equality at the Paris Peace Conference' (1978) 2 Diplomatic History; Noriko Kawamura, 'Wilsonian Idealism and Japanese Claims at the Peace Conference' (1997) 66 Pacific Historical Review 503-526; Kristofer Allerfeldt, 'Wilsonian Pragmatism? Woodrow Wilson, Japanese Immigration, and the Paris Peace Conference' (2004) 15 Diplomacy and Statecraft 545-572; Naoko Shimazu, Japan, Race and Equality: The Racial Equality Proposal of 1919 (Routledge 2009). 
each side drew up precautionary war plans. In the United States, Asian industrialists and businessmen were the target of various discriminatory policies, including limitations on land acquisition and legal disabilities in the western United States. ${ }^{63}$ To the Japanese delegation, then, racial equality became an important sticking point towards the signature of the Versailles peace treaty and their demands went furthest in articulating a desideratum for states in their relations with their inhabitants:

The equality of nations being a basic principle of the League of Nations, the High Contracting Parties agree to accord, as soon as possible, to all other nationals of States Members of the League equal and just treatment in every aspect, making no distinction, either in law or in fact, on account of their race or nationality. ${ }^{64}$

The legal effects of this article were potentially widespread. Its wording and structure, which could be described as a multilateral national treatment clause, compelled states to treat the citizens of all League member states as they did their own nationals. Moreover, the reference to 'races' meant that national minorities could potentially benefit from this treatment. But Baron Makino, the former Japanese foreign minister who introduced the provision, downplayed its immediate legal consequences by noting that the realization of absolute equality was not envisaged and that the clause merely 'enunciated' a principle while leaving a wide margin for implementation to states.

Lord Cecil, who was chairing the meeting when Makino introduced his text, immediately objected on the grounds that it raised 'extremely serious problems within the British Empire. ${ }^{65}$ China's Wellington Koo was the only delegate to voice support for the Japanese initiative, and tepidly at that: although his delegation was 'deeply interested' in the proposition, he had not received specific instructions from his government to take a definite position. ${ }^{66}$ Greek Prime Minister Venizelos, whose country had made exorbitant territorial claims from Epirus to Thrace and down to Asia Minor, conveniently suggested entrusting the matter of racial equality to the fu-

63 United States Supreme Court, Yick Wo v Hopkins (1886); Margaret Macmillan, Peacemakers: The Paris Conference of 1919 and Its Attempt to End War (John Murry 2009) 323.

64 'Tenth Meeting [of the League of Nations Commission]' of 13 February 1919, in Miller, Covenant (n 42) vol 2, 324.

65 ibid 323, 324.

66 ibid 325. 
ture League. ${ }^{67}$ The Australian delegation was among the foremost objectors, since the clause ran counter to its White Australia policy. ${ }^{68}$ The position of the dominions was among the main reasons why Britain opposed this clause so forcibly. Australia and New Zealand had made great sacrifices during the war, and although not embracing self-determination, they were quietly assessing their options for negotiating increased autonomy from the metropolis.

Other leading delegates also objected to the generalization of equality that Japan advocated. In a characteristically sulky remark, British Foreign Secretary Arthur Balfour privately told the Americans that the notion that all men are created equal was 'an eighteenth-century proposition', which he did not believe was true. All men 'of a particular nation' were equal, but the principle did not apply to a Central African man when compared to a European one. ${ }^{69}$ The mid-level American delegates generally supported the Japanese proposal, but understood it was unrealistic. After laboring over its wording, Miller soon realized that its approval would 'of course, be impossible. ${ }^{70}$

Baron Makino duly withdrew his clause from the Covenant's body and refocused his energies to include it in the Preamble. He redrafted the provision to read as a voeu, removing all coercive language. Once modified, his expansive racial equality article became a mere symbolic expression proposing 'the endorsement of the principle of equality of nations and just treatment of their nationals. ${ }^{71}$

This text, put forward during the Commission's Fifteenth Meeting, was welcomed in speeches made by the Italian, French, Chinese, Greek, and Czech delegations, primarily because it omitted the previous reference to 'races', that is, national minorities. Venizelos, his fears allayed, was now in favor: it would be very difficult to reject a preambular expression of equality among nations and their citizens, especially considering that racial minorities and immigration were excluded from its scope. He was even prepared to accept the insertion of a religious liberty clause in the Preamble to

67 ibid 325.

68 Warwick A McKean, Equality and Discrimination under International Law (Clarendon 1983) 18; Paul G Lauren, 'First Principles of Racial Equality: History and the Politics and Diplomacy of Human Rights Provisions in the United Nations Charter' (1983) 5 Human Rights Quarterly 1-26.

69 Miller, Covenant ( $\mathrm{n}$ 42) vol 1, 183.

70 ibid 184.

71 'Fifteenth Meeting [of the League of Nations Commission] of 11 April 1919. ibid vol 2, 389 . 
boot. ${ }^{72}$ Italy's Orlando also believed that invoking the notion of equality was fitting for a League that was regrouping nations of a democratic character; its explicit rejection, he continued, would represent a jarring setback. ${ }^{73}$ But both Wilson and Cecil dug in their heels. In an extremely careful speech, the President warned the Japanese delegation about the negative reception that his racial equality provision might receive outside the Commission. Cecil was markedly direct: either the formula was vague and therefore ineffective, or it had a practical significance. If the latter, it 'opened the door to serious controversy and to interference in the domestic affairs of States members of the League. ${ }^{74}$ But emboldened by the otherwise widespread support, Makino solemnly requested a vote. His preamble proposal marshalled eleven votes in favor out of seventeen (the nays were not called out). But Wilson - presiding over the meeting and therefore in control of procedural matters - insisted that unanimity was required for the motion to pass. At the French delegate's insistence that Japan had garnered the requisite votes, Wilson replied that given the 'strong opposition' that had manifested itself against the amendment, the resolution could not be considered as adopted. ${ }^{75}$ The stoic Japanese did not question this dubious explanation and racial equality was excluded from the Covenant. ${ }^{76}$

The incident almost derailed the entire Conference and the Japanese later threatened to leave the proceedings without signing the treaties. ${ }^{77}$ This would have proved catastrophic, for Italy's Orlando had already staged his exit (only to return eleven days later), and the Belgians were nearing that point. Ultimately, the controversial vote isolated Japan during the interwar

72 ibid 390-391.

73 ibid 390. As the speeches progressed, Colonel House slipped a note to Wilson: 'The trouble is that if this Commission should pass it, it would surely raise the race issue throughout the world. Although somewhat obscure, this warning was likely referring to the issue of colored peoples in America and beyond. That Wilson tolerated-if not passively advocated-racial segregation is no secret. Macmillan (n 63) 329.

74 ibid $389,390$.

75 ibid 392. Cecil merely thought it better 'that the Covenant should be silent on these questions of right. Silence would avoid much discussion. ibid.

76 According to the minutes, 'President Wilson said that no one would dream of interpreting the vote which had just been taken as a condemnation of the principle proposed by the Japanese Delegation. ibid 392. A sympathetic statement of the American delegation regarding the Japanese proposal was prepared, but not officially distributed. ibid vol 1, 465-466.

77 Mantoux (n 39) vol 1, 314. 
years. The Japanese steered away from the Western world, which they had enthusiastically orbited since the mid-nineteenth century, and fell back on aggressive nationalism.

In its final form, then, the Covenant remained silent about racial and religious equality, and contained no provisions on the equality of nations. As the drafting history shows, equality of all persons in domestic jurisdictions had not reached the level of internationally agreed rules. This is not to say that equality was not a matter of international concern under the League Guarantee, but the standard would only apply to certain rights, certain groups and to the territorial holdings of states composing the so-called Minorities Belt running from Estonia to Iraq. It follows that, during the interwar period, there was no consensus as to the existence of a general rule requiring states to hold all persons equal under their jurisdiction as between themselves or before the law. However, these elaborate discussions show a swelling concern for equality in many quarters, and the discarded provisions were later taken up by the drafters of the minorities treaties.

Further attesting to the exceptional character of the minorities regime, the Great Powers did not bear the treaty obligations that required the defeated, new and enlarged states to protect minorities. No clauses established general principles of democratic government applicable to all states, nor did they aim at a general codification of minimum standards of treatment to aliens. Any rules on equality and non-discrimination aspiring to universal recognition would have been included in the Covenant, and, as we have seen, they were deliberately rejected. When it became obvious that minority protection would only be feasible in the former belligerents' and in the new client states, Wilson's grandstanding principles were cut down to size.

\subsection{Equality in the Polish Treaty: Defining Moments}

If the Great Powers took great pains to avoid the presence of minorities clauses in the Covenant, they were just as resourceful in cajoling the smaller states into accepting these obligations. Alongside the problem of discrimination against the Jews and other minorities, the avoidance of statelessness emerged as a major concern during the drafting process of the peace treaties with the defeated and new states. Minorities living 'beyond the pale' of the law needed adequate recognition. This explains why citizenship provisions and minorities clauses were the mainstay of the socalled minorities treaties. 
The main deliberative organ at Paris was the Council, which sat at the Quai d'Orsay and was modeled around the body that had coordinated the Allied wartime efforts. ${ }^{78}$ Presided over by French Prime Minister Georges Clemenceau, the Council entrusted the minorities question to the 'Committee on New States and the Protection of Minorities', composed of expert mappers and mid-level advisors. ${ }^{79}$ In the course of its sixty-four meetings, this Committee would redraw the map of Eastern and Central Europe along the lines of national self-determination and would also draft the main provisions on minority protection. ${ }^{80}$

The minorities provisions in the treaty with Poland were the first to be adopted and their well-documented drafting history provides important insights into the purposes of the regime. Poland was first notified that the peace arrangement would tie her to international guarantees for minorities in a memorandum signed by Clemenceau, which recalled a string of nineteenth-century minority protection precedents in Europe. The Polish delegation was not amused by the prospect of giving special rights to nonPoles, but the Germans had insisted upon this guarantee to protect their co-nationals who, under the new arrangements, would find themselves outside the Mutterland. In fact, following the dissolution of Austria-Hungary, and the appearance of Poland, Czechoslovakia and Yugoslavia, the largest minority in Europe was German-speaking. ${ }^{81}$

78 That is, the Supreme Inter-allied War Council. Clive Day, 'The Atmosphere and Organization of the Peace Conference', in Edward M House and Charles Seymour (eds), What Really Happened at Paris: The Story of the Peace Conference, 1918-1919 by American Delegates (Charles Scribner's Sons 1921) 15, 17.

79 The British members were Edward H Carr and James W Headlam-Morley, whereas Manley O Hudson represented the United States with David Hunter Miller, President Wilson's closest advisor. Philippe Berthelot represented France and Mineichirō Adatci was the Japanese representative. Manley O Hudson, 'The Protection of Minorities and Natives in Transferred Territories' in House and Seymour (n 78) 204, 211.

80 See David Hunter Miller's prefatory note in Diary (n 9) vol 13. Some experts complained that they had little guidance beyond the vague principle of self-determination. They were also unaware that most of their advice was adopted by the Great Powers without much discussion. See: Harold Nicolson, Peacemaking 1919 (Grosset \& Dunlap 1965) passim.

81 'Le cas le plus caractéristique fut celui des minorités allemandes dispersées en nombre assez considérable dans presque tous les pays d'Europe centrale et orientale' Stevan Tchirkovitch, 'La règle de non-discrimination et la protection des minorités' (1951) 22 RGDIP 247, 253. See also Mark Mazower, Governing the World: The History of an Idea (Allen Lane 2012), 161-162. 
The re-establishment of the Polish state remedied what had widely been regarded as a historical injustice. Its resurgence had been trumpeted in liberal circles since the Vienna Congress of 1815, and up until Wilson's Fourteen Points. Ignacy Paderewski, the pianist and composer who was also the foremost Polish spokesperson at Versailles, embodied this romantic ideal. But new borders meant new minorities, or, as Colonel House would have it, 'to create new boundaries is always to create new troubles', and the Allies rushed to appease the defeated German Empire lest they hand over a poisoned peace. ${ }^{82}$ British Prime Minister David Lloyd George was well aware of the stakes, expressing in his Fontainebleau Memorandum that he was:

strongly averse to transferring more Germans from German rule to the rule of some other nation than can possibly be helped. I cannot conceive any greater cause of future war than that the German people, who have certainly proved themselves one of the most powerful races in the world, should be surrounded by a number of small States, many of them constituting of people who have never previously set up a stable government for themselves, but each of them containing large masses of Germans clamouring for reunion with their native land. ${ }^{83}$

These reflections contain the stuff of prophecy, for Hitler would later instrumentalize and dismantle the League system by manipulating German minorities abroad. But in 1919, the prostrate Germans had sustained heavy territorial losses and were humiliated to see many of their co-nationals come under foreign rule. It was natural that their Government should speak honorably of the League Guarantee, given their insistence that Ger-

82 Colonel House, Diary, '29 June 1919', quoted in Carole Fink, Defending the Rights of Others: The Great Powers, the Jews, and International Minority Protection, 18781938 (CUP 2004), 165.

83 Lloyd George's Fontainebleau Memorandum is dated 25 March 1919. Reproduced in Lloyd George (n 16), 405-406. Minorities in Central Europe had troubled the Great Powers in the years leading up to the Great War. There is some truth in the statement that this was a 'war of nationalities', not of states, and although the idea of minorities using states as proxies goes too far, they did come high on the political agenda of European governments after 1919. Leaders with a fascist and socialist bent benefited greatly from this air $d u$ temps. Stresemann later fashioned the new Weimar Republic as protector of German minorities abroad, a policy eagerly continued by National Socialism after 1933. Hitler's racist policies were the antithesis of minority equality, which might have something to do with equality's importance for post-war legal and constitutional developments in international organization. See Carole Fink, “Defender of Minorities”: Germany and the League of Nations, 1926-1933’ (1972) 5 Central European History 330-337. 
man kin-populations should be 'enabled to develop their German individuality, especially by being accorded the right to attend German schools and Churches.' Germany would do her part, for she was 'determined to treat the minorities on her territory in accordance with the same principles. ${ }^{34}$ With this in mind, the Allies persuaded Poland that the international guarantee was old wine in new bottles: just as the Balkan states had been enjoined to respect religious minorities after discarding the Ottoman yoke in 1878 , so was Poland being committed at her coming of age. ${ }^{85}$

All of the minorities treaties were modelled around the Polish treaty, which was the first among them to be drafted. ${ }^{86}$ The rationale behind the system of interwar group equality, as seen by the Great Powers, is captured neatly in Clemenceau's Fontainebleau memorandum to Paderewski. What is striking in this document is its reliance on old precedents, especially those emanating from the Congress of Berlin of 1878, where the Balkan states were recognized to the detriment of the Ottoman Empire:

1. In the first place, I would point out that this Treaty does not constitute any fresh departure. It has for long been established procedure of the public law of Europe that, when a State is created, or even when large accessions of territory are made to an established State, the joint and formal recognition by the Great Powers should be accompanied by the requirement that such State should, in the form of a binding international convention, undertake to comply with certain principles of government. This principle, for which there are numerous other precedents, received the most explicit sanction when, at the last general assembly of European Powers-the Congress of Berlin-the sovereignty and independence of Serbia, Montenegro, and Romania were recognised... ${ }^{87}$

its commitments were the Great Powers meeting in 1878. At Paris, the guarantor of the minority obligations was, for the first time, an interna-

84 The German reply to the Versailles treaty proposals, reproduced in LoN Publications, Les Contrepropositions de l'Allemagne au projet du Traité de Paix de Versailles, deuxième partie, II. i.b.

85 Fink, 'The Minorities Question...' (n 37), 249-274.

86 All the minorities treaties and other instruments negotiated after World War I containing minorities provisions are collected in Protection of Linguistic, Racial and Religious Minorities by the League of Nations. Provisions Contained in the Various International Instruments at Present in Force (Publications de la Société des Nations, I.B Minorités 1927).

87 'Letter of M Clemenceau to M Panderewski of 24 June 1919', reproduced in Sohn and Buergenthal (n 33), 214-15. 
tional institution. An essential element of the peace, therefore, was 'the constitution of the League of Nations as the effective guardian of international right and international liberty throughout the world: ${ }^{88}$ The League was to mark the first instance of placing groups and their members under international protection. Clemenceau elaborated on the distinction between the old and new legal policies thus:

3. It is indeed that the new Treaty differs in form from earlier Conventions dealing with similar matters. The change of form is a necessary consequence and an essential part of the new system of international relations which is now being built up by the establishment of the League of Nations. Under the older system the guarantee for the execution of similar provisions was vested in the Great Powers ... Under the new system, the guarantee is entrusted to the League of Nations. ${ }^{89}$

In their first Report to the Council of Three, the members of the Committee on New States signalled their agreement that minorities clauses on religious and political equality would be 'essential' in the Polish treaty. ${ }^{90}$ This was necessary, they argued, 'for the protection of the Jews and other minorities', as the experience in Romania had painfully shown. They added that 'this has been very strongly pressed on us by the Jewish representatives whom we have seen; it will be equally important for other minorities' Clauses defining citizenship would also be necessary in this context to avoid the problem of stateless minorities. ${ }^{91}$ The Big Three agreed, with Wilson noting that:

If we ask the new states to commit themselves purely and simply to grant equal treatment to their citizens, without providing a right of ap-

88 Lloyd George (n 16) 409.

89 'Letter of M Clemenceau to M Panderewski of 24 June 1919' (n 87).

90 On Wilson's initiative, a Council of Four comprising Wilson, Clemenceau, Lloyd George and Orlando had been established on 24 March 1919 to expedite the decision-making process. The Council of Ten continued to meet. Orlando suspended his participation when the Italian delegation walked away from the Conference over Fiume and other frustrated territorial claims on 24 April 1919. He returned with Baron Sonnino eleven days later, on 5 May, and resumed his participation in the Council. The Council's deliberations were transcribed and later published by Clemenceau's interpreter Paul Mantoux (n 39). Mantoux went on to establish the Graduate Institute of International Studies in Geneva with William Rappard in 1927.

91 'First Report to the Council of Three' dated 3 May 1919, in Miller, Diary (n 9) vol 13, 20, at 21-22: 'some clause binding Poland in respect of the citizenship and rights of these millions of her population which are not German is essential.' 
peal to the League of Nations, exactly what happened in Rumania in 1878 would happen in Poland. ${ }^{92}$

The Committee on New States finalized the draft minority protection clauses of the Polish treaty on 9 May 1919 and transmitted them to the Council of Four. ${ }^{93}$ These were duly approved and forwarded to Paderewski. A cursory review may be made at this juncture to highlight their main features. First of all, the entire treaty was framed around the League's Guarantee, which Poland had to recognize as 'obligations of international concern. The second part granted citizenship ipso facto to all persons habitually resident in Poland from 1 August 1914 onwards (in the final version, the critical date was changed to that of the treaty's entry into force.) In an accompanying report, the drafters deemed these clauses 'essential' to prevent statelessness and recalled the recurrent disenfranchisement of Jews of Romania. ${ }^{94}$ In its third section, the draft treaty required Poland to protect the life and liberty of 'all inhabitants of Poland without distinction to birth, race, nationality, language, or religion. Further clauses proclaimed equality before the law for citizens in the enjoyment of civil and political rights, freedom of religion to all inhabitants, and a special non-discrimination clause in respect of religion. All of these clauses became part of the final treaty. The article on special measures of protection for minorities followed. It would also remain largely unmodified in its final version, and ran thus:

Polish citizens who belong to racial, religious, or linguistic minorities shall be granted the same treatment and security in law and in fact as the other citizens of Poland, and in particular shall have an equal right to establish, manage, and control at their own expense charitable, religious and social institutions, schools, and other educational establishments, with the free use in them of their own language and religion. ${ }^{95}$

92 'Conversation between President Wilson, Clemenceau and Lloyd George, and Barons Sonnino and Makino' dated 17 June 1919, Mantoux (n 39) 482. The Jews in Romania were still a concern, and Romanian assurances to guarantee 'the rights and liberties' of minorities and the 'free development in language, education and worship' to alien populations were considered as empty promises. See Annex (A) to the Thirteenth Meeting, 'Note of M. Bratiano to M. Berthelot dated 27 May 1919', in Miller, Diary (n 9) vol 13, 89-90.

93 'Draft Treaty Between Poland and the Principal Allied and Associated Powers' (9 May 1919), in Miller, Diary (n 9) vol 13, 37.

94 'Second Report [of the Committee on New States]' dated 13 May 1919, ibid, 54.

95 ibid. 
This clause was inserted verbatim in the other minorities treaties. ${ }^{96}$ These special measures included the provision of adequate educational facilities in minority districts, and governmental funding for the establishment of social, religious, educational, and charitable institutions that were to be managed by the minorities. Language rights were also contemplated to accommodate for the German demands, but would also benefit Jews, Ruthenians and White Russians, especially as regards elementary education. In addition, the Polish draft treaty featured extensive provisions on the Jews, ensuring the communal authority of rabbis and the observation of the Sabbath. But the Jews' demand to be recognized as a separate nationality was not met. ${ }^{97}$ All of these provisions were adopted by consensus, except for the clause on international guarantees.

Paderewski energetically protested the supervisory measures in a memorandum, while quickly adding that Poland fully subscribed to the provisions on equal rights for minorities. ${ }^{98} \mathrm{He}$ demanded that the international guarantee be removed on the grounds that it impinged on national sovereignty and prevented the development of a national conscience. If the minorities felt that they had external protection, they would be 'encouraged to lodge their complaints against the state to which they belong before a foreign court of appeal. However, by his own admission, he regretted that the relations between Jews and Christians in Poland had become 'strained' and promised that Poland would grant 'full rights of citizenship' to all her subjects. He also opposed the far-reaching provisions on the Jews, which would result in the creation of an autonomous Jewish nation..$^{99}$ The Great Powers were sympathetic; Lloyd George, in particular, sheepishly admitted that they had gone 'perhaps a bit far' on certain points regarding the minorities clauses. ${ }^{100}$ Protecting the Jews, he continued, did not require making them 'a state within a state' and the provisions on Jewish autonomy were duly relaxed. ${ }^{101}$ As for the international guarantee, its re-

96 Albanian Treaty (art 6); Austrian Treaty (art 67); Bulgarian Treaty (art 54); Greek Treaty (art 8); Hungarian Treaty (art 58); Rumanian Treaty (art 9); Treaty with the Serb-Croat-Slovene State (art 8); Treaty with Czechoslovakia (art 8); Treaty with Turkey (art 40).

97 The Jews wanted separate electoral 'curias' allotted them in the Polish Diet and other elected bodies. 'Second Report', 'Second Report [of the Committee on New States]' dated 13 May 1919, in Miller, Diary (n 9) vol 13, 53 at 54, 56.

98 'Memorandum by M. Paderewski', ibid, 171.

99 ibid 175.

100 Council of Four, 'Meeting of 17 June 1919', in Mantoux (n 39), 482.

101 Council of Four, 'Meeting of 23 June 1919', ibid, 525. 
moval was out of the question, but its forms of implementation remained an open issue.

The Great Powers also rejected the conditional application of the minorities clauses on the basis of reciprocity. Paderewski had requested that the rights offered to Germans in Poland should be extended to Poles in Germany in a separate convention, but the Allies insisted that the League should be the sole guarantor of the rights. The abandonment of the reciprocal system of individual rights was one of the major innovations of the League regime that became ubiquitous after World War II.

The matter of enforcement was among the most controversial issues that arose during the drafting process and a variety of options were put on the table. A first series of proposals focused on the Permanent Court of International Justice pursuant to the following alternative formulae: direct access for minorities to the PCIJ; seisin of the Court by a member of the League Council; seisin by any state-member of the League; or seisin by the Council itself. Others insisted that the Council alone was competent and proposed different modalities of referral thereto. ${ }^{102}$ As these proposals circulated, Jewish lobbyists insisted that the minorities themselves should have access to the League to formulate complaints. ${ }^{103}$

Early proposals to give minorities a direct right of recourse repeatedly failed during the drafting of the peace treaties at the Paris Conference. Lord Robert Cecil had suggested that minorities and their members should be given direct access to the Permanent Court when local remedies proved futile:

The Polish Government further agrees that, as soon as the Permanent Court of International Justice shall have been established and shall have settled the necessary procedure, any Polish citizen or group of citizens who shall have been aggrieved by the failure to carry out any of the provisions referred to in the last preceding Articles may appeal to that court, and the court may give such decision and make such order as it shall think right. ${ }^{104}$

102 The approaches are surveyed in Manley O Hudson's 'Memorandum to President Wilson' dated 6 June 1919, in Miller, Diary (n 9), vol 13, 141-142.

103 For a detailed account see Fink, Defending the Rights of Others (n 82), ch 8.

104 'Suggested Additions to the Polish Treaty (Rights of Minorities)' drafted by Lord Robert Cecil, 30 May 1919, in Miller, Diary (n 9) vol 13, 103. Emphasis added. The United States and Italian delegations supported this approach. The French, British, and Japanese experts preferred that the Court's jurisdiction be limited to state-based disputes. See Council of Four, 'Meeting of 6 June 1919', Mantoux (n 39) 331. 
Cecil's idea was 'favourably received in principle', but there was doubt 'as to whether the right of appeal could be conferred unconditionally on all individuals. ${ }^{105}$ A French counterproposal gave individuals and communities the right of refer violations to a member of the League Council. ${ }^{106}$ An additional-rather odd-draft put forward by the United States and Italy would have enabled the PCIJ to attract disputes pertaining to minority groups or their members. ${ }^{107}$

Petitioning rights were also floated in the Council of Four, with Headlam-Morley reminding its members that the Covenant only enabled states to address disputes to the League. Could this right be granted to the representatives of minorities? Lloyd George was skeptical: giving 'propagandist associations' access to the League was dangerous, since the Jews were 'very litigious' and, in any event, anti-Semitism would not disappear overnight. ${ }^{108}$ Wilson believed the responsibility should fall on all member states, mainly to allay the concerns of minor powers whose populations were being enclosed in new states. This would be in accordance with the principle of equality of all states, and consequently, removed any semblance of unwarranted intervention. ${ }^{109}$ The final clauses are much more conservative and only members of the League Council were entitled to take conciliatory measures or bring legal action to the PCIJ. ${ }^{110}$ This meant that states non-members of the Council that were immediately concerned by a breach could not obtain redress if a Council member did not espouse the claim on their behalf.

105 'Suggested Additions to the Polish Treaty' (n 104) 96.

106 ibid 104. The French proposal, drafted by Berthelot, provided that 'any violation of these obligations, of which a member of the Council of the League of Nations shall have been informed, may be referred by the latter to the Council...? The Cecil proposal is reproduced alongside the Berthelot proposal at Miller, Diary (n 9) vol 13, 105.

107 'Poland agrees that the Permanent Court of International Justice to be established by the League of Nations may take jurisdiction over claims of infraction of these obligations, and that she will submit to the exercise of this jurisdiction upon such conditions and under such procedure as, by general regulations, the Court from time to time prescribe.' See: 'Draft proposed by the American and Italian Delegations', ibid, 141.

108 Council of Four, 'Meeting of 17 May 1919', Mantoux (n 39) 90, 91.

109 Council of Four, 'Meeting of 6 June 1919', ibid, 332, 333. Clemenceau limited himself to observing that the smaller states were 'very touchy' and should be dealt with carefully. ibid 332 .

110 The final clause was drafted by the French, British, and Japanese delegations. See 'Draft Proposed by the French, British and Japanese Delegations', Miller, Diary (n 9) vol 13, 141. 


\section{Concluding remarks}

The establishment of international oversight for the minorities provisions was nothing short of revolutionary. By giving the League of Nations competence to ensure the implementation of the treaties, the peacemakers made redundant the methods employed by the Concert of Europe, which were an extension of the Great Powers' interests. They also established the first international supervisory mechanism concerning the rights of groups.

But in order to denounce violations of the regime, national minorities were not entitled to have direct recourse to the bodies of the League of $\mathrm{Na}$ tions. This was a salient defect of the treaties. Instead, primary oversight of the obligations was given to states members of the League Council and to states having access to the PCIJ. Under that system, minorities sought the intercession of their kin-states and bypassed their territorial authorities in what was deemed to be an act of disloyalty.

When comparing the final outcome of the Paris Conference to Wilson's wartime desire to accord 'utmost satisfaction' to national aspirations, the achievements are considerably modest. ${ }^{111} \mathrm{His}$ attempt to generalize minority rights in the Covenant had failed and he resented the episode concerning Japan's racial equality clause. Moreover, the peacemakers also failed to impose minority protection obligations on Germany, and the attempt to develop minority protection obligations for Belgium, France, Denmark and Italy was a similar failure. ${ }^{112}$ But the successful establishment of the League changed the international system forever, not least because the fate of populations and minorities had, for the first time in modern history, played an important role in the delimitation of borders, the creation of states and the establishment of a new Covenant for peaceful international relations.

The minorities clauses also stabilized the new international order by appeasing kin-states. But domestic peace was equally important, as the clauses also aimed at integrating their beneficiaries into their new polities. Although they were later criticized for their assimilationist bent, these two aspirations were believed to be mutually reinforcing at the time. The design of the treaties addressed this dual objective by adopting a group protection rationale to justify the conferral of individual rights. This ensured the delicate equilibrium between national and international forces and

111 Wilson, 'Four Principles' (n 34).

112 See Inis Claude, National Minorities: An International Problem (HUP 1955) 35. 
fused national and international horizons. ${ }^{113}$ That is to say, individual rights were given a new context of meaning after their elevation to the international plane. Unquestionably, liberal individual rights had enjoyed great currency in national laws before the Great War, especially in Western Europe and America. Their transnational development during the nineteenth century through reciprocity and nationality cemented their normative value. But these personal freedoms owe their international elevation to the principle of nationalities, which imbued them with its cosmopolitan international programme and its legal embodiment after the Great War through the internationalization of equality as a legal standard of protection.

113 To paraphrase Gadamer's dialectical concept. See Hans-Georg Gadamer, Truth and Method (Seabury Press 1975). 
